\title{
Community Structure of Riparian Community of Sematang Borang River of South Sumatera
}

\author{
Yetty Hastiana
}

University of Muhammadiyah Palembang; Jend. A. Yani St. 13 Ulu Palembang;

email: yet_hasti@yahoo.com.

\begin{abstract}
ABSTRAK
Vegetasi riparian adalah sebagai ekoton antara habitat teresterial dengan sistem perairan (sungai). Penyangga riparian berfungsi untuk menjaga kelestarian fungsi sungai dengan cara menahan atau menangkap tanah (lumpur) yang tererosi serta unsur hara dan bahan kimia termasuk pestisida yang terbawa dari lahan dibagian kiri kanan sungai agar tidak masuk ke perairan. Sungai Sematang Borang merupakan bagian dari Daerah Aliran Sungai (DAS) Musi, Sungai Sematang Borang memiliki karaketeristik struktur sungai dengan panjang seitar $5 \mathrm{~km}$, lebar sungai mencapai $70 \mathrm{~m}$ dan kedalaman sekitar $10 \mathrm{~m}$. Saat ini sungai ini mulai terancam mengalami penurunan kualitas baik fisik, kimia maupun biologi Selain kehilangan habitat alami ikan yang akan berdampak pada penurunan kelimpahan dan biodiversity, perairan ini juga mengalami abrasi pada sisi kiri kanan tebing sungai. Keberadaan vegetasi riparian menjadi penting, selain untuk mencegah abrasi, juga berperan dalam produksi serasah. Produksi serasah berkontribusi dalam transfer bahan organik vegetasi ke dalam tanah. Unsur hara yang dhasilkan dari proses dekomposisi serasah dalam tanah sangat penting bagi kelangsungan hidup vegetasi dan sebagai sumber detritus bagi ekosistem dalam menyokong kehidupan organisme akuatik. Pentingnya kontribusi vegetasi riparian dalam suatu ekosistem, maka perlu dilakukan penelitian terhadap diversitas dan profil vegetasi. Kajian aspek vegetasi, diperkuat dengan melakukan pengamatan terhadap kondisi fisik kimia perairan Sematang Borang. Parameter fisik kimia perairan yang diamati meliputi: suhu, kedalaman, kecepatan arus, COD, BOD, DO, pH, dan Salinitas. Penelitian menerapkan metode ekologi deskriptif kuantitatif dan kualitatif, untuk analisis kualitas fisik kimia perairan didukung analisis laboratorium dan survei. Hasil penelitian teridentifikasi 15 species riparian dengan kategori indeks keanekaragaman riparian 0,09-1,03 dan memiliki pola penyebaran cenderung berkelompok. Merujuk pada kategori aspek hayati kawawasan perairan Sematang terancam tercemar. Kondisi fisik dan kimia perairan berupa parameter kecerahan, kadar COD dan DO berkorelasi kta terhadap nilai indeks keanekaragaman vegetasi riparian. Sementara suhu lingkungan, DO dan salinitas berkorelasi kuat terhadap pola penyebaran riparian.
\end{abstract}

Kata Kunci: Kualitas sungai, Sungai Sematang Borang, Vegetasi Riparian

\section{ABSTRACT}

Riparian vegetation are the plant community as tree, grasses and shrubs or agency of various forms and types of vegetation that growth in the left and right edges of the river. Riparian buffer due to preserve the stream function by holding or catching the ground (mud ) eroded by nutrients and chemicals including pesticides carried from the field on the left of the river right from entering the waters. Sematang Borang river is part of the Musi Watershed,Sematang Borang River have river characteristic structure with a length about $5 \mathrm{~km}$, river width about $70 \mathrm{~m}$ and depth about $10 \mathrm{~m}$. Recently this river have been threatened about deteriorated physical, chemical and biological quality . The Threat is not only about habitat natural loss and fish decrease the abundance and biodiversity impact, but also suffered abrasion on the left side and right side of river canyon . that's make riparian 
vegetation to be the important, beside to prevent abrasion, they're also as instrument in the Serasah production. Serasah production contributes to the transfer of organic matter to the soil vegetation. nutrients production from serasah decomposition processes in the soil is essential to the survival of vegetation and ecosystems as a source of detritus for aquatic organisms to supporting life. Is's make the importance of riparian vegetation, ecological studies are necessary to analyze the presence of riparian vegetation. Study aspects of vegetation, reinforced by the observation of the physical condition of the water chemistry as mature Forms. The physical parameters of water chemistry were observed include: temperature, depth, current speed, $\mathrm{COD}, \mathrm{BOD}, \mathrm{DO}, \mathrm{pH}$, and salinity. This Studies using quantitative and qualitative to descriptive ecology, for physical and chemical water quality have analysis from laboratory analysis and the survey. The results showed 15 species found in the category of riparian species diversity is relatively low level (grades $H^{\prime}<1$ ) the group spreading pattern $(\mathrm{S} 2 / \mathrm{X}>1)$. The results of correlation analysis showed a weak correlation variation, strong and fairly between the physical parameters of the chemical riparian diversity .

Keywords: riparian vegetation, river quality, Sematang Borang River

\section{Pendahuluan}

Tumbuhan riparian merupakan sumberdaya alam tropik yang memiliki fungsi strategis bagi ekosistem, yaitu sebagai penyambung dan penyeimbang ekosistem darat dan laut. Berdasarkan data yang diperoleh, mengungkapkan bahwa provinsi Sumatera Selatan sebagian wilayahnya berupa kawasan hutan produksi, perkebunan besar dan sebagian berupa kawasan perkotaan (Anonimous, 2010). Pemanfaatan lainnya berupa kawasan pertanian lahan basah, lahan kering dan kawasan hutan resapan. Data ini cukup memberikan gambaran pentingnya penataan kembali penggunaan lahan di kawasan DAS (Daerah Aliran Sungai) Sematang Borang, dalam arti perlu arahan yang lebih jelas agar kawasan budidaya yang ada di sepanjang Sungai Sematang Borang apabila memungkinkan dapat dikonversi sebagai kawasan lindung atau berfungsi lindung (Noordwijki dkk., 2004; Sumiarsih, 2009; Anonimous, 2010).
Sebagai sumberdaya alam, tumbuhan riparian memiliki fungsi dan peranan penting, baik secara ekologis maupun ekonomis (Furze dkk., 1996; Anonimous, 2008; Adepran, 2010). Secara ekologis berperan dalam mendukung eksistensi lingkungan fisik dan biota. Bagi lingkungan fisik berfungsi sebagai penahan arus ombak, penahan angin, pengendali banjir, penetralisir pencemaran dan penahan intrusi air laut. Bagi lingkungan biota adalah sebagai daerah spawning grounds, mencari makanan dan zona nursery grounds berbagai jenis biota perairan. Sedangkan potensi ekonomis yaitu, dengan adanya serasah dan biomassa tumbuhan riparian menjadi sumber pakan biota perikanan yang akan mendukung produktifitas perikanan (Payne, 1986; Barnes dan Mann, 1991; Cunningham dan Saigo, 1999).

Peralihan fungsi ekosistem vegetasi riparian berdampak pada munculnya abrasi, turunnya mutu air perairan serta musnahnya 
sejumlah spesies yang hidup pada lingkungan sungai. Dampak ekologis akibat berkurang dan rusaknya ekosistem tumbuhan riparian adalah hilangnya berbagai spesies flora dan fauna yang berasosiasi dengan ekosistem tumbuhan riparian, yang dalam jangka panjang akan mengganggu keseimbangan vegetasi riparian dan ekosistem akuatik secara umum (Cunningham and Saigo, 1999; Semiun, dkk., 2013).

Fenomena yang telah diuraikan di atas menjadi salah satu pertimbangan utama mengapa penelitian ini dilakukan. Penelitian mengenai ekologi vegetasi riparian khususnya struktur komunitas riparian belum pernah dilakukan di kawasan perairan Sungai Sematang Borang ini. Bukan berarti penelitian ini menjadi tidak berarti. Lebih lanjut hasil penelitian ini akan menjadi landasan bagi pengembangan konsep ekologi perairan, antara lain misalnya: pengelolaan ekosistem lowland, penerapan pola konservasi hayati kawasan DAS (Daerah Aliran Sungai), estimasi dan prediksi daya dukung lingkungan (carring capasity) sungai khususnya DAS Sematang Borang, maupun dalam penerapan model konservasi biodiversity vegetasi akuatik.

\section{Tujuan Penelitian/Tujuan Penulisan}

Sebagai tujuan utama dari penelitian ini adalah menganalisis struktur komunitas vegetasi riparian di kawasan perairan Sungai Sematang Borang. Tujuan selanjutnya adalah menganalisis kualitas dan kondisi perairan yang meliputi paramter fisik dan kimia Sungai Sematang Borang.

Sebagai tindak lanjut dari capaian kedua tujuan penelitian di atas, adalah melakukan analisis korelasi antara kualitas fisik kimia perairan terhadap kondisi hayati khususnya pada vegetasi riparian. Sehingga akan diperoleh estimasi dan prediksi keterkaitan antara kondisi fisik kimia perairan dengan keragaman dan pola distribusi vegetasi riparian.

\section{Metode Penelitian/Penulisan}

Penelitian ini mengambil lokasi di Sungai Sematang Borang. Penentuan sampling secara stratified sampling, melalui penentuan lokasi sampling pada 3 stasiun pengamatan, meliputi: stasiun 1 inlet/kearah hulu berada di wilayah Desa Sako dengan titik koordinat geografis $02^{\circ} 55,174$ LS dan $104^{\circ} 48,203$ BT, bagian tengah sebagai stasiun 2 berada di wilayah Desa Kenten Laut dengan titik koordinat geografis $02^{\circ} 53,457$ LS dan $104^{\circ} 46,301$ BT, dan bagian stasiun 3 sebagai outlet/ lebih ke arah hilir berada di wilayah Desa Gasing dengan titik koordinat geografis $02^{\circ} 48,084$ LS dan $104^{\circ} 44,624$ BT. Pada setiap stasiun pengamatan ditentukan sebanyak 10 plot pengamatan pada sisi kiri dan kanan sungai, plot berbentuk kuadrat. Keseluruhan 
sampling berjumlah 60 plot pengamatan dengan ukuran masing-masing plot seluas $2 \times 2 \mathrm{~m}$.

Alat yang digunakan untuk analisis fisik kimia perairan, meliputi: termometer, $\mathrm{pH}$ meter, keeping secchi, bambu, botol plastik, alumunium foil, kamera digital. Alat untuk melakukan analisis vegetasi riparian, meliputi: patok penyangga, alat ukur, gunting, tallyset, buku identifikasi dan sistematika tumbuhan, alat tulis dan kamera digital. Bahan yang digunakan: larutan pengencer, larutan natrium hidroksida $(\mathrm{NaOH})$, larutan asam sulfat $\left(\mathrm{H}_{2} \mathrm{SO}_{4}\right)$ dan larutan $\mathrm{Na}_{2} \mathrm{SO}_{3}$, dan formalin.

Cara kerja yang diterapkan untuk pengumpulan data tumbuhan riparian, meliputi: melakukan observasi langsung dilapangan, menentukan jumlah dan titik sampling, membuat plot, mengamati, mengidentifikasi, mendeskripsikan, menghitung, mencatat, membuat dokumentasi serta membuat awetan herbarium pada setiap spesies riparian yang di dapat. Hasil pengamatan dikoleksi dan dicatat dalam tabel distribusi.

Pengumpulan data fisik Perairan Sungai Sematang Borang meliputi data: kedalamam sungai, suhu air dan tingkat transparansi air. Sedangkan data kimia dengan mengukur: kadar Oksigen terlarut,
COD, BOD, pH, dan salinitas (Fachrul, 2008).

Analisis vegetasi riparian, dilakukan dengan menghitung beberapa parameter ANVEG, meliputi: kerapatan, frekuensi dan Indeks Nilai Penting (INP), Variansi, dan Indeks Keragaman Shannon- Winner. Adapun rumusan yang dipakai pada masingmasing parameter tersebut, adalah (Fachrul, 2008):
a) Kerapatan relatif (Kpr)
b) Frekuensi relatif (Fr)
c) Indeks Nilai Penting (INP)
d) Variansi $\left(\mathrm{S}^{2}\right)$
e) Indeks Keragaman Shannon- Winner.

Keragaman jenis tanaman sungai ditentukan berdasarkan jumlah jenis yang ditemui. Untuk melihat nilai penting jenis riparian dilakukan analisis vegetasi yang meliputi:

a) Kerapatan relatif (Kpr), yaitu jumlah individu sejenis dalam luas tertentu.

$$
\mathrm{Kpr}=\frac{\text { jumlah spesies }}{\text { total spesies }} \times 100 \%
$$

b) Frekuensi Relatif (Fr): prosentase kehadiran tiap-tiap jenis dalam sebaran plotnya.

$\mathrm{Fr}=\frac{\text { frekuensi spesies }}{\text { total frekuensi spesies }} \times 100 \%$

c) Indeks Nilai Penting (INP), yaitu sebagai dasar penentuan komunitas tumbuhan merupakan penjumlahan dari 
nilai-nilai relatif dari ketiga parameter tersebut.

$\mathrm{INP}=\mathrm{Kpr}+\mathrm{Fr}$

d) Rumus variansi

$S^{2}=\frac{\sum \mathrm{xi}^{2}-\left(\frac{\sum \mathrm{xi}}{\mathrm{n}}\right)^{2}}{(\mathrm{n}-1)}$

$\mathrm{S}^{2}=$ variansi

$\mathrm{Xi}=$ jumlah individu

$\mathrm{n}=$ jumlah plot yang diamati

e) Rumus rata-rata individu

$\bar{X}=\frac{\sum \mathrm{xi}}{n}$

Keterangan:

$\overline{\mathrm{X}}=$ rata-rata

$\mathrm{Xi}=$ jumlah individu per plot ke-i

$\mathrm{n}=$ jumlah plot yang diamati.

Dari hasil data variasi $\left(\mathrm{S}^{2}\right)$ dibagi ratarata dari tiap spesies (X) untuk menetukan bentuk penyebarannya yaitu:

$\mathrm{S}^{2} / \mathrm{X}<1=$ pola penyebarannya acak
$\mathrm{S}^{2} / \mathrm{X}=1=$ pola penyebarannya merata $\mathrm{S}^{2} / \mathrm{X}>1=$ pola penyebarannya berkelompok

f) Indeks keragaman Shannon-Winner

$$
\mathbf{H}^{\prime}=-\sum \frac{\frac{n i}{N} \log n i}{N}
$$

Penentuan tingkat keragaman mengacu pada kategorisasi tingkat keragaman, jika (Rachman, 2011):

$\mathrm{H}^{\prime}<1,0 \quad$ : keanekaragamn rendah $1,0<\mathrm{H}^{\prime}<3,322$ : keanekaragaman sedang $\mathrm{H}^{\prime}>3,322$ : keanekaragaman tinggi

Selanjutnya untuk mengetahui korelasi antara kondisi abiotik (fisik kimia) perairan terhadap keragaman dan pola distribusi vegetasi rivarian dilakukan uji regresi linear dengan melihat interval kategorisasi kekuatan hubungan korelasi seperti pada Tabel 1. Uji regresi linear didukung oleh program software SPSS versi 16.0.

Tabel 1. Interval Kategorisasi Kekuatan Hubungan Korelasi

\begin{tabular}{|l|l|l|}
\hline No & Nilai R & Keterangan \\
\hline 1 & 0 & tidak ada korelasi \\
\hline 2 & $0,00-0,25$ & korelasi sangat lemah \\
\hline 3 & $0,25-0,50$ & korelasi cukup \\
\hline 4 & $0,50-0,75$ & korelasi kuat \\
\hline 5 & $0,75-0,99$ & korelasi sangat kuat \\
\hline 6 & 1 & korelasi sempurna \\
\hline
\end{tabular}

Sumber: Sarwono, 2011.

Data mengenai penentuan skala Parameter yang digunakan adalah jumlah kualitas perairan terkait dengan kondisi jenis (Soerjani, 1989; Zahidin, 2008; keragaman flora dapat dilihat pada Tabel 2. Dewiyanti, 2012). Tabel standar dari Soerjani 
dan telah dimodifikasi, merupakan patokan lingkungan hidup dari aspek vegetasi. untuk mengevaluasi tingkat kualitas

Tabel 2. Skala kualitas berdasarkan lingkungan hidup komponen flora

\begin{tabular}{|c|c|c|c|}
\hline Skala Kualitas & Kriteria & Flora & Indeks Keanekaragaman \\
\hline 1 & Sangat Buruk & $1-5$ species & $<0,75$ \\
\hline 2 & Buruk & $6-10$ species & $0,75-1,50$ \\
\hline 3 & Sedang & $11-20$ species & $2,51-2,25$ \\
\hline 4 & Bagus & $21-30$ species & $>3$ \\
\hline 5 & Sangat Bagus & $>30$ & $26-3$ \\
\hline
\end{tabular}

Keterangan : 1=sangat buruk ; $2=$ buruk ; $3=$ sedang ; 4=bagus ; $5=$ sangat bagus

Sumber : Soerjani, 1989

\section{Pembahasan}

1. Analisis Keanekaragaman dan Pola penyebaran Vegetasi Riparian

Data hasil penelitian mengenai species dominasi, keanekaragaman serta pola distribusi vegetasi riparian dapat dilihat pada Tabel 3 dan Gambar 1.

riparian yang ditemukan dan tingkat

\section{Kelimpahan Spesies Riparian}

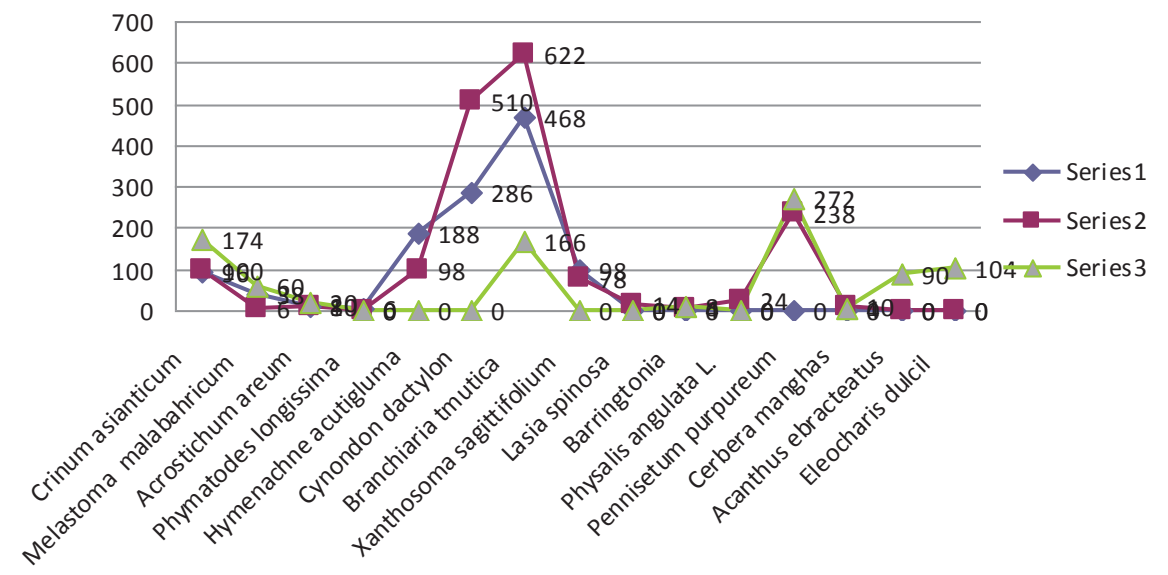

Gambar 1. Kelimpahan vegetasi riparian pada area DAS Sematang Borang

Sedangkan nilai keragaman indeks Shannon-Winner pada setiap stasiun bervariasi. Pola penyebaran species pada setiap stasiun pengamatan cenderung berkelompok. 
Tabel 3. Indeks Keanekaragaman dan Pola Distribusi Tumbuhan Riparian

\begin{tabular}{|c|c|c|c|}
\hline & \multicolumn{3}{|c|}{ Stasiun } \\
\hline Indeks Keanekaragaman Shannon-Wienner Tumbuhan Riparian & 1 & 2 & 3 \\
\hline Pola Distribusi Tumbuhan Riparian & 0,09 & 1,03 & 0,09 \\
\hline
\end{tabular}

Sumber: hasil olah data, 2013.

Kategori skala kualitas lingkungan jika ditinjau dari jumlah species tumbuhan seperti dirujuk pada Tabel 2. memiliki kategori sedang dengan jumlah species sebanyak 15 jenis. Jika ditinjau dari indeks keanekaragaman Shannon-Wienner semua area sampling menunjukan kriteria buruk, berdasarkan justifikasi yang dirujuk pada Tabel 2, dengan asumsi pada area sampling memiliki rentang indeks keanekaragaman antara $0,09-1,03$.

Kecenderungan penentuan kualitas lingkungan perairan yang didasarkan atas kajian aspek bioindikator hayati perlu ditindak lanjuti dengan melakukan analisis terhadapo kualitas fisik kimia perairan.

\section{Analisis Kondisi Fisik Kimia Perairan Sungai Sematang Borang}

Berdasarkan hasil pengamatan terhadap parameter transparansi (kecerahan) sungai, menunjukkan stasiun 1 memiliki nilai kecerahan relatif rendah dibanding dua area sampling lainnya. Dinamika kecerahan air dipengaruhi oleh beberapa faktor, antara lain (Semiun $d k k$.., 2013). aspek topografi, erosi, sedimen, laju run off, tutupan lahan wilayah DAS (daerah aliran sungai).

Data ini memperkuat asumsi bahwa kondisi DAS Sematang Borang terancam mengalami pencemaran.

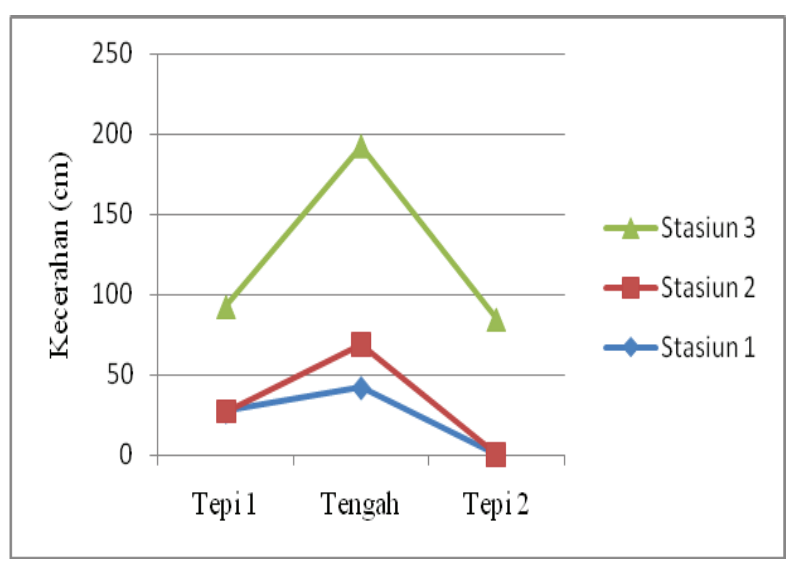

Gambar 2. Rata-Rata Transparansi Sungai pada Stasiun Pengamatan (hulu, tengah, hilir) dengan 3 sub sampling. 
Berdasarkan dekripsi pada Gambar 3, suhu lingkungan (Semiun $d k k$., 2013). Suhu lingkungan relatif meningkat pada hilir Diungkapkan juga bahwa semakin rendah sungai. Data ini memperkuat asumsi bahwa, ketinggian suatu tempat, maka suhu tingginya aktivitas manusia pada bagian out lingkungan cenderung meningkat. let/hilir sungai berkontribusi meningkatkan

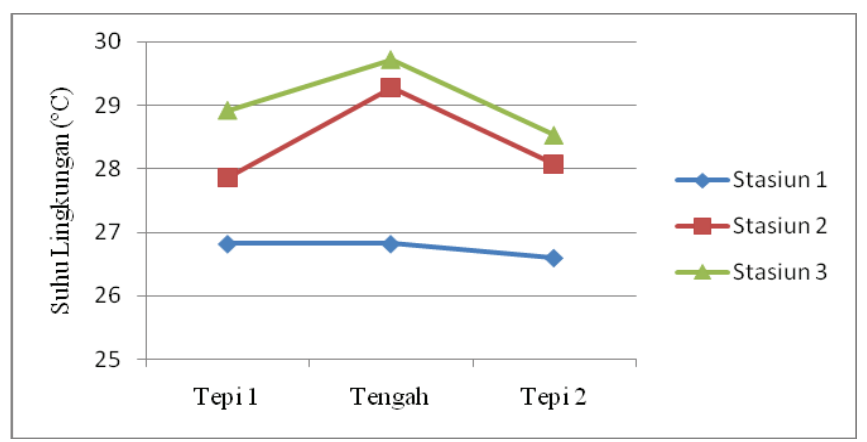

Gambar 3. Rata-Rata Suhu Lingkungan Sungai pada Stasiun Pengamatan

Hasil penelitian pada parameter suhu dan out let/hilir Sungai Sematang Borang perairan, bagian tengah dan hilir cenderung ditemukan sejumlah aktivitas kegiatan mengalami peningkatan relatif lebih tinggi pertanian, industri dan sejumlah pemukiman (Goudie, 1994; Payne, 1986). Berdasarkan padat. Penduduk memanfaatkan sungai untuk hasil observasi pada area sampling tengah aktivitas MCK.

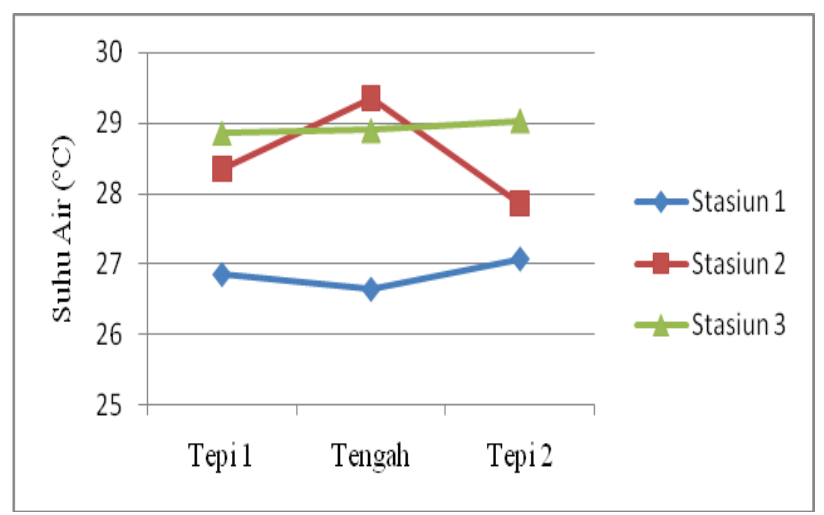

Gambar 4. Rata-Rata Suhu Air Sungai pada stasiun pengamatan.

Kebutuhan Oksigen biokimia dan suatu karaktersitik yang menunjukkan jumlah biochemical oxygen demand (BOD) adalah oksigen terlarut yang diperlukan 
mikroorganisme untuk menguraikan bahan organik dalam kondisi aerob (Nuraini, 2013).

BOD merupakan salah satu indikator pencemaran organik pada ekosistem akuatik. Nilai BOD $<2$ mengindikasikan kondisi sungai masih dalam kategori baik. Tingginya nilai BOD mengindikasikan badan perairan tercemar bahan organik (Mason, 1994; Semiun dkk.l, 2013). Berdasarkan hasil analisis nilai BOD diketahui bahwa perairan Sematang Borang kategori belum terakumulasi bahan organik baik pada bagian inlet, midlet maupun outlet perairan, dengan rentang nilai BOD antara 1,29 sampai 1,61.

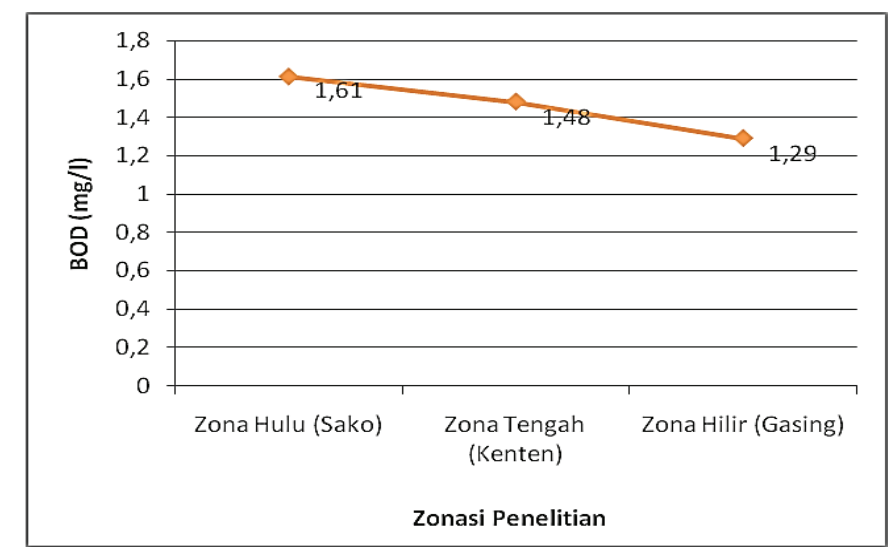

Gambar 5. Rata-Rata BOD pada stasiun pengamatan.

COD (chemical oxygen demand) mengindikasikan bahwa perairan berada pada merupakan salah satu indikator pencemaran organik pada ekosistem akuatik, merupakan zona bahaya bahkan telah masuk kategori tercemar. kebutuhan oksigen kimia untuk reaksi Nilai COD tertinggi ditemukan pada oksidasi terhadap bahan buangan di dalam air. Nilai COD >10 mengindikasikan bahwa sungai tersebut sudah tercemar (Kato, 2013).

Ekosistem dengan nilai COD tinggi mengindikasikan bahwa perairan terakumulasi bahan buangan. Hasil penelitian pada tiga stasiun seperti yang disajikan pada Gambar 6, menunjukkan nilai COD antara 13,73 mg/l - 19,67 mg/l. Kondisi ini 1994). 


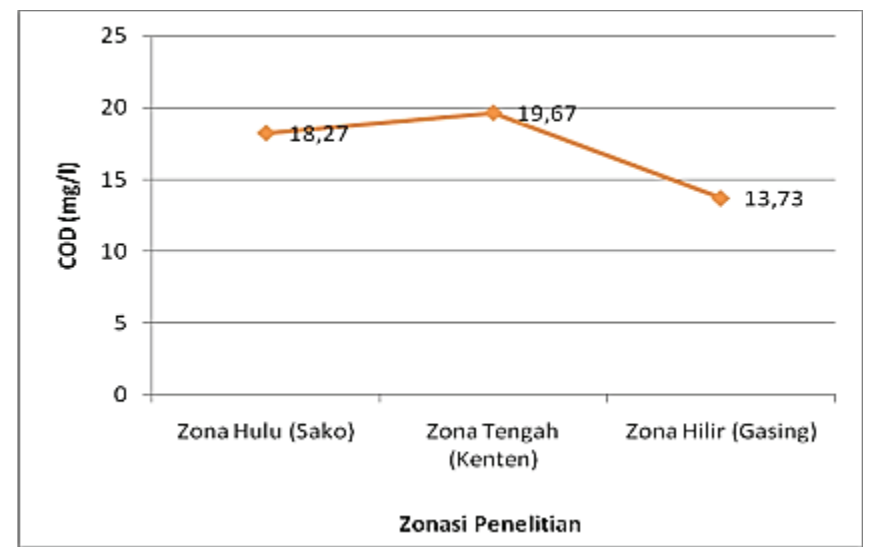

Gambar 6. Rata-Rata COD pada Stasiun Pengamatan

Oksigen terlarut (DO) suatu perairan dapat digunakan sebagai indikator kualitas kimia perairan dan lebih jauh akan berpengaruh terhadap keberadaan ikan dari golongan karnivora yang terintegrasi dalam siklus rantai makanan ekosistem akuatik bagian tengah dan outlet kategori tercemar. (Kato, 2013).

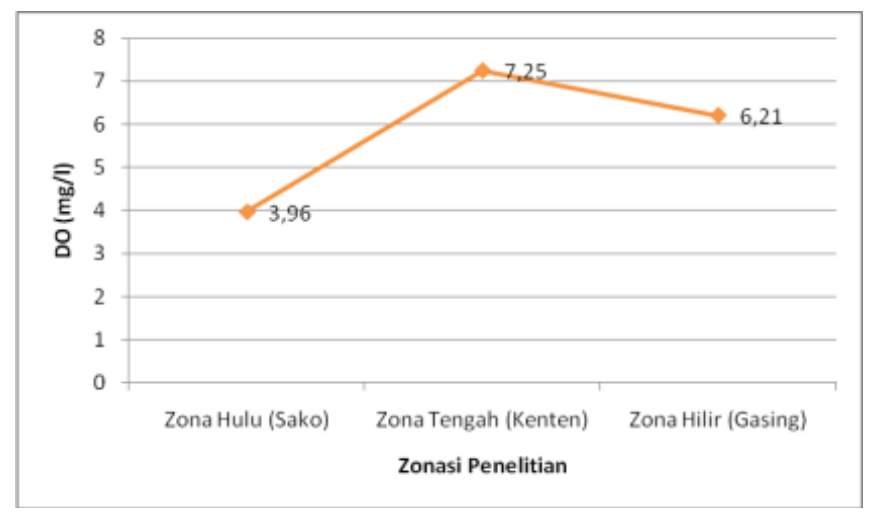

Gambar 7. Rata-rata DO pada Stasiun Pengamatan.

Pengukuran $\mathrm{pH}$ merupakan faktor Nilai $\mathrm{pH}$ menunjukkan derajat penting, karena banyak reaksi kimia dan keasaman atau kebasaan perairan. Nilai pH biokimia perairan sangat tergantung pada yang ideal bagi kehidupan organisme akuatik kondisi pH perairan (Anonymous, 2013). umumnya berkisar antara 7-8,5. Kondis 
perairan yang sangat basa maupun asam akan membahayakan kelangsungan hidupnya karena terjadi gangguan pada proses metabolisme dan repirasi organosme akuatik (Rizal, 2009). Selain itu nilai pH juga mempengaruhi proses nitrifikasi ekosistem perairan.

Data mengenai $\mathrm{pH}$ perairan dapat dilihat pada 8 , perairan relatif cenderung asam, berada pada kisaran 4,9 - 6, dimana kondisi paling asam di bagian hilir dengan $\mathrm{pH}$ antara 4,9-5,1. Derajat keasaman $(\mathrm{pH})$ memiliki korelasi sangat kuat terhadap kelangsungan hidup tumbuhan dan hewan. Sehingga sering digunakan sebagai petunjuk untuk menyatakan baik atau tidaknya kondisi air sebagai media hidup (Wati, 2012).

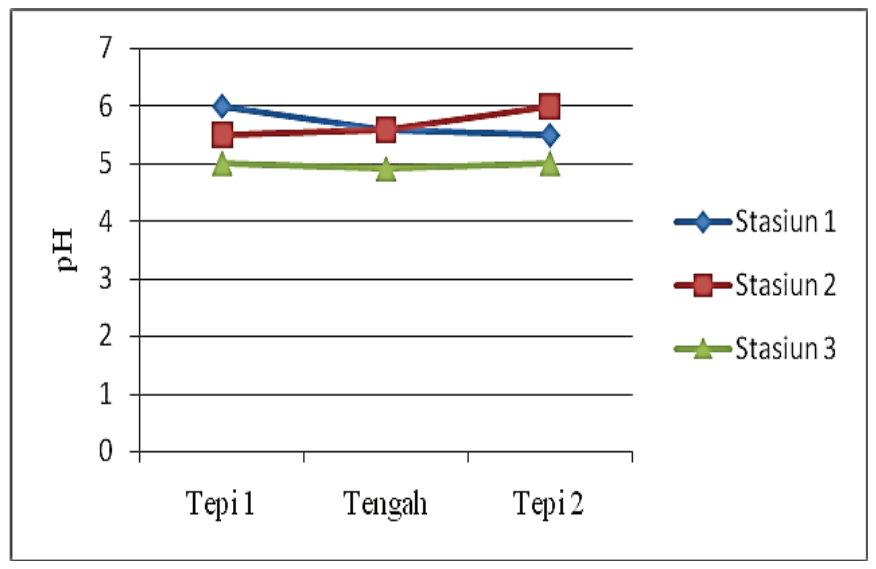

Gambar 8. Rata-Rata pH pada setiap stasiun.

Salinitas menunjukkan jumlah garam terlarut dalam satuan volume air yang biasa dinyatakan dengan satuan promil (\%o). Salinitas berpengaruh terhadap tekanan osmotik air. Perubahan salinitas secara cepat menyebabkan kematian organisme perairan, termasuk vegetasi makrophyta maupun mikrophyta. Salinitas dipengaruhi oleh pencampuran air laut dan tawar, curah hujan, evavorasi, siklus harian dengan pasang surut air. Perairan tawar biasanya sulit mentolerir salinitas di atas 5\%o (Praweda, 2009).

Berdasarkan Gambar 9, rata-rata nilai salinitas perairan antara $0,7-0,94 \%$. Salinitas semakin ke hilir cenderung meningkat, dikarenakan peluang bercampurnya air tawar dan laut semakin besar. Intensitas hujan juga mempengaruhi kadar salinitas, semakin tinggi evaporasi maka kadar salinitas semakin tinggi (Rachaman, 2011; Kato, 2013). 


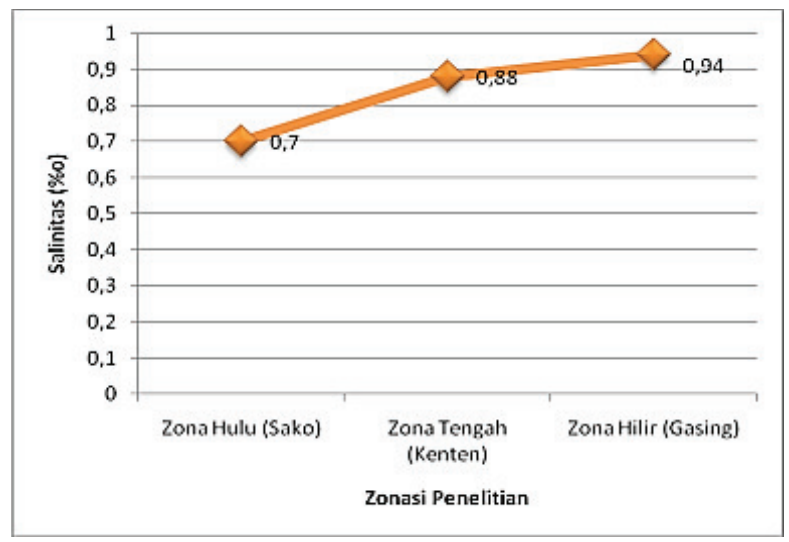

Gambar 9. Rata-rata Salinitas pada setiap stasiun.

3. Korelasi antara Kondisi Fisik Kimia Perairan dengan Keragaman dan mengkaji keterhubungan antara beberapa Pola Distribusi Vegetasi Riparian

Setelah melakukan analisis indeks dengan kecenderungan munculnya variasi keragaman dan distribusi vegetasi riparian kondisi keanekaragaman dan pola distribusi pada Sungai Sematang Borang, dilanjutkan ekologis vegetasi riparian. dengan pengukuran dan pengamatan terhadap kondisi fisik dan kimia perairan. Tahap

Tabel 4. Koefisien korelasi parameter fisik kimia sungai terhadap keanekaragaman dan distribusi tumbuhan riparian

\begin{tabular}{|l|c|c|c|c|}
\hline \multicolumn{1}{|c|}{$\begin{array}{c}\text { Parameter Fisik } \\
\text { Kimia }\end{array}$} & Nilai korelasi & $\begin{array}{c}\text { Indeka Keanekaragaman } \\
\text { tumbuhan riparian }\end{array}$ & Nilai Korelasi & $\begin{array}{c}\text { Distribusi } \\
\text { tumbuhan riparian }\end{array}$ \\
\hline Kecerahan air & 0,641 & korelasi kuat & 0,155 & korelasi lemah \\
Suhu Lingk. & 0,245 & korelasi lemah & 0,706 & korelasi kuat \\
Suhu air & 0,329 & korelasi sedang & 0,042 & korelasi sedang \\
BOD & 0,108 & korelasi lemah & 0,415 & korelasi lemah \\
COD & 0,628 & korelasi kuat & 0,213 & korelasi kuat \\
DO & 0,743 & korelasi kuat & 0,981 & korelasi lemah \\
pH & 0,500 & korelasi sedang & 0,013 & korelasi kuat \\
Salinitas & 0,277 & korelasi sedang & 0,729 & \\
\hline
\end{tabular}

Sumber: hasil olah data analisis statistik, 2013 
Berdasarkan uji korelasi beberapa parameter fisik kimia perairan seperti pada Tabel 4. terlihat bahwa tiga parameter fisik kimia perairan yaitu: kecerahan air, nilai COD dan DO berkorelasi kuat terhadap indeks keanekaragaman riparian. Sedangkan yang berkorelasi kuat terhadap pola distribusi vegetasi riparian adalah suhu lingkungan, nilai DO dan salinitas.

Kondisi kecerahan air suatu perairan sangat dipengaruhi tingkat erosi, sedimen dan laju run off. Lebih jauh lagi, kumulasi material sediment akan menyatu membentuk dataran lumpur. Ekosistem lumpur selanjutnya dapat membentuk substrat bagi pertumbuhan vegetasi di sempadan sungai, diantaranya vegetasi riparian (Zahidan, 2008; Adepran, 2010.).

Kecepatan difusi oksigen dari udara, tergantung pada beberapa faktor, antara lain: kekeruhan air, suhu, salinitas, pergerakan masa air dan udara, arus, gelombang pasang surut (Calinvaux, 1973; Kato, 2011; Dewiyanti, 2012; Semiun dkk., 2013). Pendapat ini mendukung hasil penelitian, dimana kehadiran oksigen terlarut sangat dipengaruhi oleh kekeruhan air. Kekeruhan air mengindikasikan dinamika laju run off dengan ikutan material sedimennya. Kondisi ini secara kumulatif dan intens akan membentuk kumulasi material berupa lumpur sedimen pada area sempadan sungai. Kumulasi lumpur inilah yang perlahan akan menjadi media dan habitat bagi pertumbuhan vegetasi riparian.

Oksigen terlarut (DO) dapat berasal dari proses fotosintesis tumbuhan air dan oksigen dari udara yang masuk ke dalam air. Konsentrasi DO sendiri dalam air tergantung pada suhu dan tekanan udara (Miller, 1998).

Nilai COD yang dibutuhkan perairan untuk mengoksidasi senyawa kimia yang masuk ke dalam perairan. Besarnya nilai COD mengindikasikan tingginya kehadiran senyawa kimia di dalam perairan.

Dalam mempertahankankan fungsi ekologinya, ekosistem akuatik memiliki mekanisme alami yang terstruktur dan unik. Indikasi keberlimpahan vegetasi riparia erat kaitannya dengan ketersediaan oksigen. Kehadiran senyawa kimia dan materialmaterial organik yang merupakan bagian dari dinamika ekosistem akuatik menjadi stimulus bagi kehadiran species tertentu (Barnes dan Mann, 1991; Naiman dan Henri, 1990).

\section{Kesimpulan}

Teridentifikasi 15 species tumbuhan penyusun vegetasi riparian di Sungai Sematang Borang, Palembang, dengan rentang nilai indeks keanekaragaman riparian antara 0,09-1,03. Pola distribusi setiap 
species riparian di kawasan perairan Sematang Borang cenderung berkelompok.

Berdasarkan kategori aspek hayati yang dilihat dari nilai indeks keanekaragaman vegetasi riparian, bahwa kawasan Sungai Sematang Borang terindikasi terancam tercemar.

Kondisi fisik dan kimia berupa kecerahan air, kadar COD dan DO berkorelasi kuat terhadap nilai indeks keanekaragaman vegetasi riparian. Sementara suhu lingkungan, kadar DO dan salinitas akan berkorelasi kuat terhadap pola distribusi riparian.

\section{Pustaka}

Adepran. 2010. Mengenal Zona Riparian. (Online).http://adepran.wordpress.co $\underline{\mathrm{m} / 2010 / 10 / 16 / m e n g e n a l-z o n a-}$ riparian/, diakses pada tanggal 13 Juni 2013.

Anonim. 2008. Riparian Zone. (Online). http://agritusi.com/archives/265, diakses pada tanggal 23 April 2013

Anonimous. 2010. Sungai Musi. (on line), http://palembangnews.com/index.php ?option $=$ com content $\&$ view $=$ article $\&$

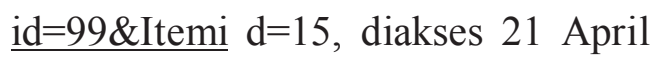
2013.
Anonimous. 2013. Ekosistem. (on line), http://id.wikibooks.org/wiki/Subjek:B iologi/Materi:Ekosistem, diakses 25 April 2013.

Ardansamman. 2012. Ekosistem Sungai. (Online).http://shafa.ardansamman.co m/wp/archives/153/, diakse pada tanggal 27 April 2013.

Barnes, R. S. K., and Mann. K. H. 1991. Fundamentals of Aquatic Ecology. Hongkong: The University Press.

Calinvaux, Paul A. 1973. Introduction to Ecology. America: John Willey \& Sons, Inc.

Cunningham, W.P., and B.W. Saigo. 1999. Environmental Science: a global concern. Fifth edition. McGraw-Hill, Boston.

Dewiyanti, Irma. Diversity and percent covers of aquatic plants in Lake Laut Tawar ecosystem, Takengon, Aceh Province. Depik, 1(2): 125-130. Agustus 2012 ISSN 2089-7790.

Effendi, H. 2000. Telaah Kualitas Air Bagi Pengelolaan Sumberdaya Alam Lingkungan Perairan. IPB Press: Bogor. 
Fachrul, Melati Ferianita. 2008. Metode Sampling Bioekologi. Cetakan Kedua.

Sinar Grafika Obset: Jakarta.

Furze, Brian. Terry De Lacy and Jim Birckhead. $1996 . \quad C u l t u r e$, Conservation and Biodiversity. England: John Willey \& Sons Ltd.

Goudie, Andrew. 1994. The Human Impact on the Natural Environment. Fourth Edition. The MIT Press: Cambridge, Massachusetts.

Kato, Syifa.2011. Kualitas Air (on line), (http://syifakatoooo.blogspot.com/201 1/04/kualitas-air.html, diakses 24 April 2013.

Mason, C.F. 1994. Biology of Freshwater. Copublished in the United States with John Wiley \& Sons, Inc., 605 Third Avenue, New Yock.

Miller, G.Tyler, JR. 1998. Living in the Environment: Principles, Connections and Solutions. Tenth Edition. Brooks/Cole Publishing Company, Pacific Grove, CA.

Naiman, Robert J. and Henri Decamps. 1990. The Ecology and Management of Aquatic-Terrestrial Ecotones. France: Man and The Biosphere Series.
Noordwijk, van Meine et al. 2004. Peranan Agroforestri dalam Mempertahankan Fungsi Hidrologi Daerah Aliran Sungai (DAS). Agrivita Vol. 26 No.1 Maret 2004 ISSN : 0126 - 0537

Nuraini, Rabiah. 2013. pengertian BOD dan COD. (on line), (http://rabaiahnuraini.blogspot.com/2 013/03/01/pengertian-bod-dan codd.html,diakses 26 April 2013.

Payne, A.I. 1986. The Ecology of Tropical Iakes and Rivers. Jhon Wiley \& Sons: Chister-New Yock-Toronto-BrisbaneSingapore.

Praweda. 2009. Ekosistem Air Tawar (on line),(http://.ui.ac.id/bebas/v12/spons or/SponsorPendamping/Praweda/Biol ogi/0034\%20Bio201-7e.htm, diakses 29 April 2013.

Rachaman, Mochamad Ridhana. 2011. Menghitung tingkat sanilitas pada air. (Online) http://ridhorachman.blogspot.com/20 $\underline{11 / 03 / \text { menghitung-tinkat-salinitas- }}$ pada-air.html, diakses tanggal 24 April 2013.

Ridwan. 2012. Pengertian Ekosistem, Susunan dan Macam Ekosistem. (on line),(http://ridwanaz.com/umum/biol ogi/pengertian-ekosistem-dan- 
macam-ekosistem/, diakses 19 April 2013.

Rizal, Aboi. 2009. Teknik Pengambilan Sampel. (on line), (http://rizalbbapujungbatee.blogspot.com/2009/0 5/teknik-pengambilan-sampel.html, diakses 25 Aporil 2013,

Seminu, Gradict Chatarina et al. Degradation of Riparian Tree Diversity on Spring Fed Drains and Its Impacts to Water Quality, East Java. The Journal of Tropical Life Science. VOL. 3, NO. 2 , pp. 120 - 126, June, 2013

Sumiarsih, Eni dkk. 2009. Kerapatan dan Produksi Serasah Tumbuhan Riparian Dominan Perairan Sungai Siak di Desa Belading Kecamatan Sabak Auh Kabupaten Siak Provinsi Riau. Pekanbaru: Himpunan Alumni Fakultas Perikanan dan Ilmu Kelautan Universitas Riau.

Wati, Erna Pristiyo. 2012. Penentuan Komponen Biotik dan Abiotik Lingkungan Perairan (on line), (http://riwayathidupkubloggergratis.bl ogspot.com/2012/04/penentuankomponen-biotik-dan abiotik.html, diakses 26 April 2013.

Zahidin, Muhammad. 2008. Kajian Kualitas Air Di Muara Sungai Pekalongan
Ditinjau Dari Indeks Keanekaragaman Makrobenthos Dan Indeks Saprobitas Plankton. Tesis. Program Studi Magister Manajemen Sumberdaya Pantai. Program Pasca Sarjana Universitas Diponegoro. Semarang. 